\title{
PECTINASE PRODUCTION BY PENICILLIUM VIRIDICATUM RFC3 BY SOLID STATE FERMENTATION USING AGRICULTURAL WASTES AND AGRO-INDUSTRIAL BY-PRODUCTS
}

\author{
Dênis Silva; Eduardo da Silva Martins; Roberto da Silva; Eleni Gomes*
}

Laboratório de Bioquímica e Microbiologia, IBILCE, Universidade Estadual Paulista, São José do Rio Preto, SP, Brasil

Submitted: September 13, 2002; Returned to authors for corrections: January 08, 2002; Approved: December 05, 2002

\begin{abstract}
Pectin lyase and polygalacturonase production by newly isolated Penicillium viridicatum strain Rfc3 was carried out by means of solid state fermentation using orange bagasse, corn tegument, wheat bran and mango and banana peels as carbon sources. The maximal activity value of polygalacturonase (Pg) $\left(30 \mathrm{U}_{\mathrm{g}} \mathrm{g}^{-1}\right)$ was obtained using wheat bran as carbon source while maximal pectin lyase (Pl) $\left(2000{\mathrm{U} . \mathrm{g}^{-1}}^{-1}\right)$ activity value was obtained in medium composed of orange bagasse. Mixtures of banana or mango peels with sugar cane bagasse resulted in increased $\mathrm{Pg}$ and $\mathrm{Pl}$ production compared to fermentations in which this residue was not used. The mixture of orange bagasse and wheat bran (50\%) increased the production of Pg and Pl to $55{\mathrm{U} . \mathrm{g}^{-1}}$ and $3540 \mathrm{U} . \mathrm{g}^{-1}$ respectively. Fractions of Pg and Pl, isolated by gel filtration in Sephadex G50, presented optimum activity at pH 5.0 and 10.5 respectively. Maximal activity of $\mathrm{Pg}$ and $\mathrm{Pl}$ fractions was determined at $55^{\circ} \mathrm{C}$ and $50^{\circ} \mathrm{C}$ respectively. $\mathrm{Pg}$ was stable in neutral $\mathrm{pH}$ range and at $40^{\circ} \mathrm{C}$ whereas $\mathrm{Pl}$ was stable in acidic $\mathrm{pH}$ and at $35^{\circ} \mathrm{C}$, for $1 \mathrm{~h}$.
\end{abstract}

Key words: Penicillium viridicatum, polygalacturonase, pectin lyase, wastes, by-product

\section{INTRODUCTION}

A large number of microorganisms, isolated from different materials, have been screened for their ability to degrade polysaccharides present in biomass, producing protein or higher value products $(7,29,39)$.

Among depolimerizing microbial enzymes, pectinolytic enzymes, which degrade pectin present in varying abundance in the middle lamella and primary cell walls, have great commercial importance for various industrial applications like improving juice yields and clarity $(3,12)$. The use of liquefying enzymes for mash treatment results in improvement of juice flow, leading to a shorter press-time, without the necessity for pressing aids (35). At the same time, pectin is broken down to such an extent that the viscosity of mash is reduced (28). Other areas of application include the paper and pulp industry (36), waste management (13), animal feed (6) textile industry (4).

Pectinolytic enzymes are classified according to their mode of attack on the galacturonan part of the pectin molecule. They can be distinguished from pectin methylesterases (EC 3.1.11.1), that deesterify pectins to low methoxyl pectins or pectic acid, and form pectin depolymerases, that split the glycosidic linkages between galacturonosyl (methyl ester) residues. Polygalacturonases split glycosidic linkages next to free carboxyl groups by hydrolysis while pectate lyases split glycosidic linkages next to free carboxyl groups by $\beta$-elimination. Both endo types of Pgs and PAls (EC 3.2.1.15 and EC 4.2.2.2, respectively) are known to randomly split the pectin chain. Exo-Pgs (EC 3.2.1.67) release monomers or dimmers from the non-reducing end of the chain, whereas exo-PAls (EC 4.2.2.9) release unsaturated dimmers from the reducing end. Highly methylated pectins are degraded by endo-pectin lyases (Pl; EC 4.2.2.10) and also by a combination of pectin esterases with $\mathrm{Pg}$ or $\mathrm{PAl}(10,34)$.

Major impediments to the exploitation of commercial enzymes are their yield, stability, specificity and the cost of production. New enzymes for use in commercial applications with desirable biochemical and physico-chemical characteristics and a low cost of production have been the focus of much research.

\footnotetext{
* Corresponding author. Mailing address: Universidade Estadual Paulista, Departamento de Biologia. Rua Cristóvão Colombo, 2265, Jardim Nazareth.
} 15054-000, São José do Rio Preto, SP, Brasil. Tel.: (+5517) 221-2393. Fax: (+5517) 221-2390. E-mail: eleni@bio.ibilce.unesp.br 
Application of agro-industrial wastes as carbon sources in enzyme production processes reduces the cost of production, and also helps in solving problems with their disposal (33).

In this paper we report the production of pectolytic enzymes by a newly isolated strain of Penicillium viridicatum $\mathrm{Rfc} 3$ by solid-state fermentation using agricultural wastes and agroindustrial by-products. Some physico-chemical characteristics of the enzymes fractions are presented.

\section{MATERIALS AND METHODS}

\section{Microorganism}

The Penicillium vericatum Rfc 3 strain used in this study was recently isolated from decaying vegetable collected in Bady Bassit-SP/Brazil. The strain was maintained on potato dextrose agar (PDA) slopes as a stock culture.

\section{Media, cultivation of microorganism and enzyme production}

The solid substrates were prepared as follows:

a) Orange bagasse. The pellet of orange bagasse (pressed mixture of pulp and peel) was provided by Citrovita Agroindustrial Ltda/Catanduva/SP/Brazil. Chemical analysis indicated that the dry material was composed of $11.8 \%$ fiber, $6.4 \%$ protein, $63.0 \%$ nitrogen, $6.7 \%$ ash, $19.0 \%$ total sugar (9.0\% reducing sugar) and $0.1 \%$ pectin. The material was ground and particles sieved by a Bender USS 230 strainer and dried at $80^{\circ} \mathrm{C}$.

b) Sugar cane bagasse: The sugar cane bagasse was provided by Usina de Açúcar e Álcool São Domingos/Catanduva/ $\mathrm{SP} /$ Brazil. Chemical analysis indicated that the dry material was composed of $75.0 \%$ fiber, $0.5 \%$ protein, $5.0 \%$ nitrogen, $3.4 \%$ ash, $10.4 \%$ total sugar (3.5\% reducing sugar).The material was ground and particles sieved by a Bender USS 230 strainer and dried at $80^{\circ} \mathrm{C}$.

c) Wheat bran: This material was purchased from the local market, dried and used untreated. Chemical analysis indicated that the dry material was composed of $8.1 \%$ fiber, $15.7 \%$ protein, $65.0 \%$ nitrogen, $4.6 \%$ ash, $16.7 \%$ total sugar $(5.2 \%$ reducing sugar).

d) Banana and mango were purchased from the local market. The peels were removed, dried and ground to about $2 \mathrm{~mm}$ in particle size. The total and reducing sugar contents in banana peel were $26.2 \%$ and $13.2 \%$, respectively and in mango peel were $39.3 \%$ and $19.5 \%$, respectively. No other chemical analyses were performed. The dried peels were not submitted to any chemical treatment.

e) Corn teguments were supplied by Laboratório de Cereais/ Departamento de Engenharia de Alimentos/IBILCE/UNESP/ São José do Rio Preto/SP/Brasil, as a residue from corn processing. The total and reducing sugar content were $10.4 \%$ and $3.5 \%$, respectively. No other chemical analyses were performed.
Solid-state fermentation (SSF) was carried out using a 250 $\mathrm{ml}$ Erlenmeyer flask containing $5 \mathrm{~g}$ of sterilized substrate $\left(120^{\circ} \mathrm{C} /\right.$ 40min) inoculated with $10 \mathrm{ml}$ aliquots of conidia suspension (approx. $10^{7}$ spores/g dry substrate) obtained from a 7-day agar slant culture suspended in sterile Tween 80 solution. After inoculation, $10 \mathrm{ml}$ of nutrient solution, composed of $0.1 \%$ $\mathrm{NH}_{4} \mathrm{NO}_{3} ; 0.1 \% \mathrm{NH}_{4} \mathrm{H}_{2} \mathrm{PO}_{4} ; 0.1 \% \mathrm{MgSO}_{4} \times 7 \mathrm{H}_{2} \mathrm{O}$, was added to each flask. The final moisture content of the medium was approximately $67 \%$. The substrates were mixed in proportions of $50 \%$.

The cultivation was carried out at $30^{\circ} \mathrm{C}$ for 14 days. At $48 \mathrm{~h}$ intervals, the solid fermented material corresponding to one Erlenmeyer flask was mixed with $40 \mathrm{ml}$ distilled water, stirred for $40 \mathrm{~min}$, filtered under vacuum and centrifuged. The supernatant was used as crude enzyme solution.

\section{Enzyme activity measurements}

Polygalacturonase $(\mathrm{Pg})$ activity was determined by measuring the release of reducing groups from citrus pectin using the 3,5-dinitrosalicylic acid (DNS) reagent assay (25). The reaction mixture containing $0.8 \mathrm{ml} 1 \%$ citric pectin $67 \%$ methoxylated (Braspectina-Limeira/SP/Br) in $0.2 \mathrm{M}$ acetate buffer, pH 5.0 and $0.2 \mathrm{ml}$ of crude enzyme solution, was incubated at $50^{\circ} \mathrm{C}$ for $10 \mathrm{~min}$. One unit of enzymatic activity (U) was defined as the amount of enzyme which releases one mmol of galacturonic acid per minute.

Pectin lyase ( $\mathrm{Pl}$ ) activity was determined by measuring the increase in absorbance at $235 \mathrm{~nm}$ of substrate solution $(0.8 \mathrm{ml}$ $1 \%$ citric pectin in $0.2 \mathrm{M}$ tris- $\mathrm{HCl}$ buffer, $\mathrm{pH} 8.5$ ) hydrolyzed by $0.2 \mathrm{ml}$ enzyme solution, at $50^{\circ} \mathrm{C}$. One unit of enzymatic activity (U) was defined as the amount of enzyme which releases $1 \mu \mathrm{mol}$ of unsaturated uronide per minute, based on the molar extinction coefficient ( $\varepsilon=5500)$ of the unsaturated products $(2)$.

The enzyme production was expressed in units per gram of initial dry solid substrate $\left(\mathrm{U}_{\mathrm{g}} \mathrm{g}^{-1}\right)$.

\section{Separation of the pectinases}

The crude enzyme $(300 \mathrm{ml})$, obtained after 2 and 14 cultivation days on orange bagasse and wheat bran mixture $(50 \% \mathrm{w} / \mathrm{w})$, was slowly dispersed in two volumes of iced ethanol and maintained at $-20^{\circ} \mathrm{C}$ for 2 hours. The resulting precipitate was collected by centrifugation (20,000xg for $20 \mathrm{~min}$ ), dissolved in the smallest possible volume of tris- $\mathrm{HCl}$ buffer $(50 \mathrm{mM}, \mathrm{pH}$ 7.4) and applied to a Sephadex G 50 column (3 x 100cm) equilibrated with $50 \mathrm{mM}$ tris-HCl buffer ( $\mathrm{pH}$ 7.4). The enzymes were eluted with the same buffer.

\section{Enzyme characterization}

The fractions of $\mathrm{Pg}$ and $\mathrm{Pl}$, obtained from gel filtration, were used for the characterization assays.

Optimum $\mathrm{pH}$ and temperature for enzyme activity: The enzyme activity was determined at $50^{\circ} \mathrm{C}$, in different $\mathrm{pH}$ using sodium 
acetate (pH 3.0-5.0), citrate-phosphate ( $\mathrm{pH} 5.0-7.0)$, tris- $\mathrm{HCl}(\mathrm{pH}$ 7.0-8.5) and glycine- $\mathrm{NaOH}(\mathrm{pH} 8.5-11.0)$ as buffers. The optimum temperature within the $30-70^{\circ} \mathrm{C}$ range was determined by incubation of the reaction mixture at optimum $\mathrm{pH}$.

$\mathrm{pH}$ and temperature stability: Enzyme solution was dispersed (1:1) in 0.2M buffer $\mathrm{pH} 3.0-5.0$ (sodium acetate), $\mathrm{pH}$ 5.0-7.0 (citrate-phosphate), $\mathrm{pH} 7.0-8.5$ (tris- $\mathrm{HCl}$ ) and $\mathrm{pH}$ 8.5-11.0 (glycine- $\mathrm{NaOH}$ ) and maintained at $25^{\circ} \mathrm{C}$ for $24 \mathrm{~h}$. An aliquot was used to determine the remaining activity at the optimum $\mathrm{pH}$ and temperature for enzymes. For the temperature stability determination, the enzyme solution was incubated at different temperatures $\left(30^{\circ} \mathrm{C}-70^{\circ} \mathrm{C}\right)$ for $1 \mathrm{~h}$ at $\mathrm{pH}$ 5.0. An aliquot was withdrawn and placed on ice before assaying for residual pectinase activity at optimum $\mathrm{pH}$ and temperature.

\section{RESULTS AND DISCUSSION}

\section{Production of pectinases by SSF}

The fungus Penicillium viridicatum Rfc3, when grown in a media containing wheat bran, orange bagasse, corn tegument, banana and mango peels or mixture of these materials with sugar cane bagasse $(50 \% \mathrm{w} / \mathrm{w})$ produced polygalacturonase and pectin lyase. Enzyme production by SSF was analyzed during 14 days and the experiments were carried out in five assays (Table 1). Polygalacturonase production peaked between the $4^{\text {th }}$ and the $6^{\text {th }}$ days of cultivation when the substrates contained no sugar cane bagasse. In media composed of orange bagasse, wheat bran and corn tegument, a first peak was obtained after the $4^{\text {th }}$ of fermentation and a second and smaller peak, at the $12^{\text {th }}$ day (data not shown). The maximal activity value of $\operatorname{Pg}\left(30 \mathrm{U} \cdot \mathrm{g}^{-1}\right)$ was obtained using wheat bran as carbon source.

$\mathrm{Pl}$ production in media composed by only one type of waste was observed in the beginning of fermentation and peaks of production occurred between the $2^{\text {th }}$ and the $10^{\text {th }}$ days. The maximal $\mathrm{Pl}$ activity value was obtained in media composed of orange bagasse (2000 $\left.\mathrm{U.g}^{-1}\right)$ (Table 1).

Mixtures of high sugar content wastes such as banana $(13.2 \%)$ and mango $(19.5 \%)$ peels with sugar cane bagasse resulted in increase in the $\mathrm{Pg}$ and $\mathrm{Pl}$ production compared to fermentations in which the bagasse was not used (Table 1). It is known that the synthesis of pectinases by fungi is subject to catabolic repression by high free sugar concentration affecting inducible and constitutive enzymes $(1,19)$. On the other hand, the consistence and size of particles in media composed of banana and mango peels interfered in their packing during the fermentation, since the bed remained static (nonmixed system), affecting the gas and heat exchange within the system (27). The addition of fibrous material as sugar cane bagasse increased the interparticle spacing, possibly increasing the aeration and diffusion of nutrient and enzyme, as shown by Mitchell et al. (26). When solely sugar cane bagasse was used as carbon source, there was no growth of $P$. viridicatum (data not shown), indicating that the microorganism was not able to hydrolyse enough cellulose and hemicellulose fibers to support mycelium formation. These supposition was confirmed by the low level of cellulase and xilanase produced by this fungus in the experiments (data not shown). The sugar cane bagasse appeared to be only a solid inert support, being microorganism growth and enzyme production stimulated by wastes addition. The use of sugar cane bagasse as support is suitable for the growth of filamentous fungi and it allowed the utilization of highconcentration substrate solutions (30). This supposition is confirmed in solid-state culture of Aspergillus niger (31).

Our results indicated that, in addition to the effect of reducing sugar concentration, $\mathrm{Pg}$ and $\mathrm{Pl}$ production was influenced by media composition, reaching higher values in media containing high pectin and nutrient concentration

Table 1. Production of pectinase $\left({\mathrm{U} . \mathrm{g}^{-1}}^{-1}\right)$ by $P$. vidiricatum $\mathrm{Rfc} 3$ in solid state fermentation using agricultural wastes and agroindustrial by-products.

\begin{tabular}{lcccc}
\hline \multicolumn{1}{c}{ Substrate } & \multicolumn{2}{c}{ Polygalacturonase } & \multicolumn{2}{c}{ Pectin lyase } \\
\cline { 2 - 5 } & $\begin{array}{c}\text { Maximal production } \\
\left(\mathrm{Ug}^{-1}\right)\end{array}$ & $\begin{array}{c}\text { Cultivation } \\
(\text { days })\end{array}$ & $\begin{array}{c}\text { Maximal production } \\
\left(\mathrm{Ug}^{-1}\right)\end{array}$ & $\begin{array}{c}\text { Cultivation } \\
(\text { days })\end{array}$ \\
\hline Wheat bran & 30.0 & 4 & 1200 & 8 \\
Orange bagasse & 12.0 & 6 & 2000 & 4 \\
Mango peel & 5.0 & 4 & 450 & 4 \\
Corn tegument & 10.0 & 4 & 650 & 2 \\
Banana peel & 7.5 & 6 & 150 & 10 \\
Sugar cane bagasse and wheat bran & 27.0 & 8 & 1500 & 10 \\
Sugar cane bagasse and orange bagasse & 9 & 8 & 2500 & 12 \\
Sugar cane bagasse and mango peel & 15.0 & 8 & 1500 & 10 \\
Sugar cane bagasse and corn tegument & 5.0 & 8 & 500 & 10 \\
Sugar cane bagasse and banana peel & 15.0 & 6 & 1000 & 12 \\
Orange bagasse and wheat bran & 55.2 & 8 & 3540 & \\
\hline
\end{tabular}


(orange bagasse and wheat bran). The mixture of orange bagasse and wheat bran showed to be the best medium for pectinase production, with $55.2 \mathrm{U}$ and $3540 \mathrm{U}$ of $\mathrm{Pg}$ and $\mathrm{Pl}$ per gram of substrate, respectively. The effect of different carbon sources on pectinase synthesis by fungi in submerged and solid-state fermentation have already been studied, and it is generally agreed that the optimum medium for the enhanced production of extracellular pectinase is that containing pectic materials as an inducer $(14,16,20,29,40)$.

The quantities of $\mathrm{Pg}$ and $\mathrm{Pl}$ obtained in our study were high compared to those reported for pectinolytic strains such as Aspergillus niger $(25 \mathrm{U} \mathrm{Pg}$ and $350 \mathrm{U} \mathrm{Pl}$ per gram of substrate), P. italicum (6U Pl/g e $25 \mathrm{U} \mathrm{Pg/g}$ ), P. frequentans (3.4 U Pg/g) and A. foedidus (1000 U Pl/g) cultivated on solid substrates $(8,9,18,21)$. However, the comparison of enzyme levels produced by different organisms is not straightforward, since distinct culture conditions and enzyme activity determinations have been used.

These results showed that SSF was suitable for pectinase production by $P$. viridicatum using agricultural and agroindustrial wastes and by-products.

Assays to evaluate the effect of temperature incubation $\left(28^{\circ} \mathrm{C}\right.$ and $30^{\circ} \mathrm{C}$ ) and initial $\mathrm{pH}$ of the medium (4.5 and 5.0) on Pg and $\mathrm{Pl}$ production were carried out. The results indicated that maximal quantity of Pg was not significantly influenced by temperature or $\mathrm{pH}$, but the production profile of this enzyme, during fermentation period, varied as a function of initial substrate $\mathrm{pH}$ (Fig. 1a; 1b). At $\mathrm{pH}$ 5.0, the peak of Pg production occurred in the $4^{\text {th }}$ day whereas at $\mathrm{pH} 4.5$, in the $8^{\text {th }}$ day. The $\mathrm{pH}$ values seem to influence enzyme stability (Fig 1a; 1b). On the other hand, $\mathrm{Pl}$ production decreased at $30^{\circ} \mathrm{C}$, although the $\mathrm{pH}$ effect was similar to that observed for Pg production.
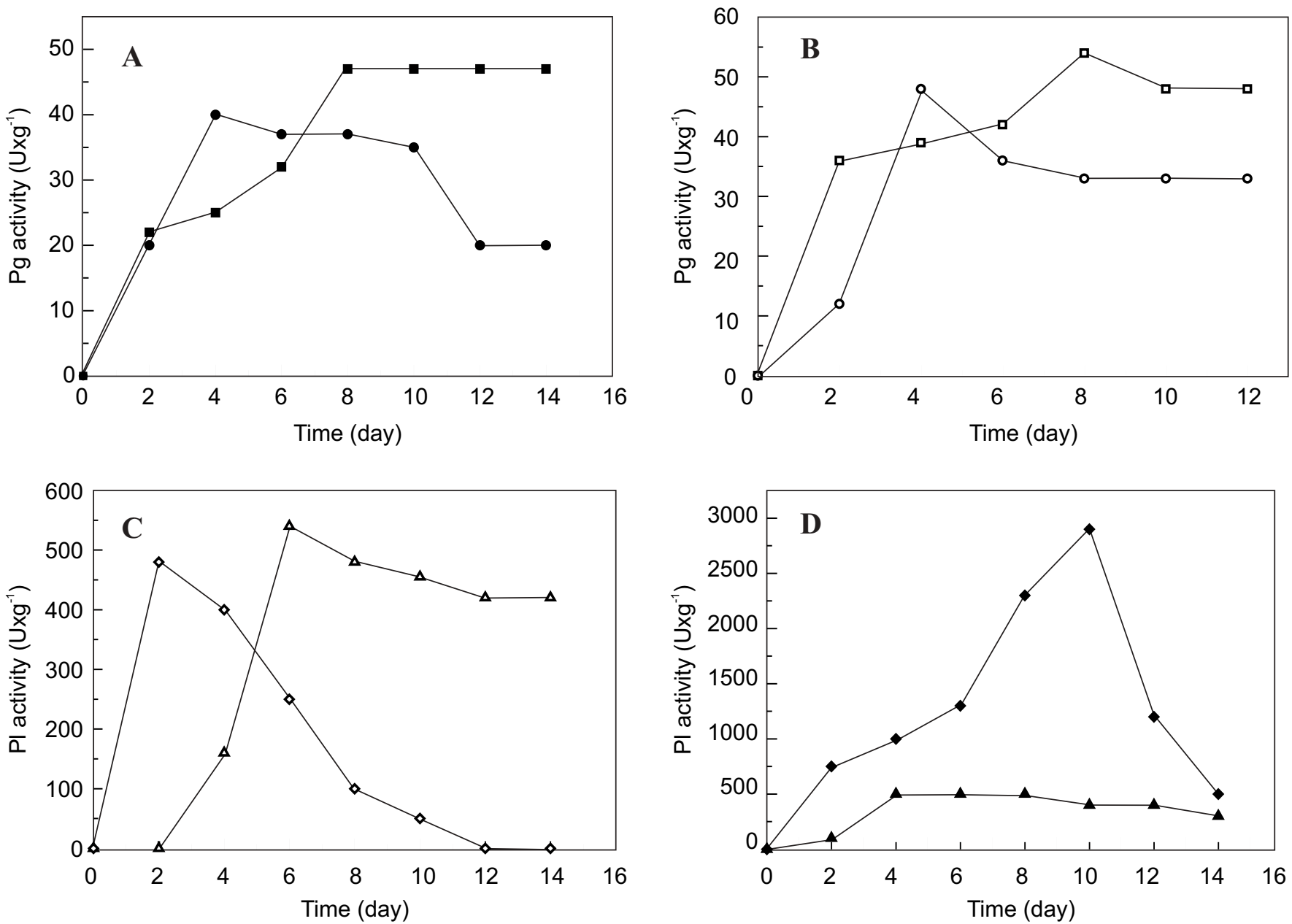

Figure 1. Pectinase production by Penicillium viridicatum in orange bagasse and wheat bran mixture (1:1). Full symbol (A,D): $28^{\circ} \mathrm{C}$ and open symbol (B,C) $30^{\circ} \mathrm{C}$. Polygalacturonase: $\square \mathrm{opH} 4.5 ; \bullet \bigcirc \mathrm{pH} 5.0 ;$ Pectin lyase $\Delta \triangle \mathrm{pH} 4.5 ; \diamond \mathrm{pH}$ 5.0. 


\section{Enzymes separation by gel filtration}

Gel filtration in Sephadex G50 of the crude enzyme solutions obtained after two days of fermentation resulted in two peaks of Pg and four peaks of Pl (Fig. 2a). Enzyme solution, obtained from medium after 14 days of fermentation, presented three peaks of $\mathrm{Pg}$ and two peaks of $\mathrm{Pl}$ (Fig. 2b). The position of the enzymes in the chromatogram suggests that two Pgs (I and II) and one Pl (IV) are produced during the whole fermentation period, while three Pl (I, II and III) are observed only in the initial stage of fermentation. After 14 days, both $\mathrm{Pg}$ (III) and $\mathrm{Pl}$ (V) are produced.

The comparison between $\mathrm{Pg}$ and $\mathrm{Pl}$ production during growth of $P$. viridicatum suggests a sequential induction of these enzymes. Sequential production of pectinases have been reported by various authors for different microorganisms
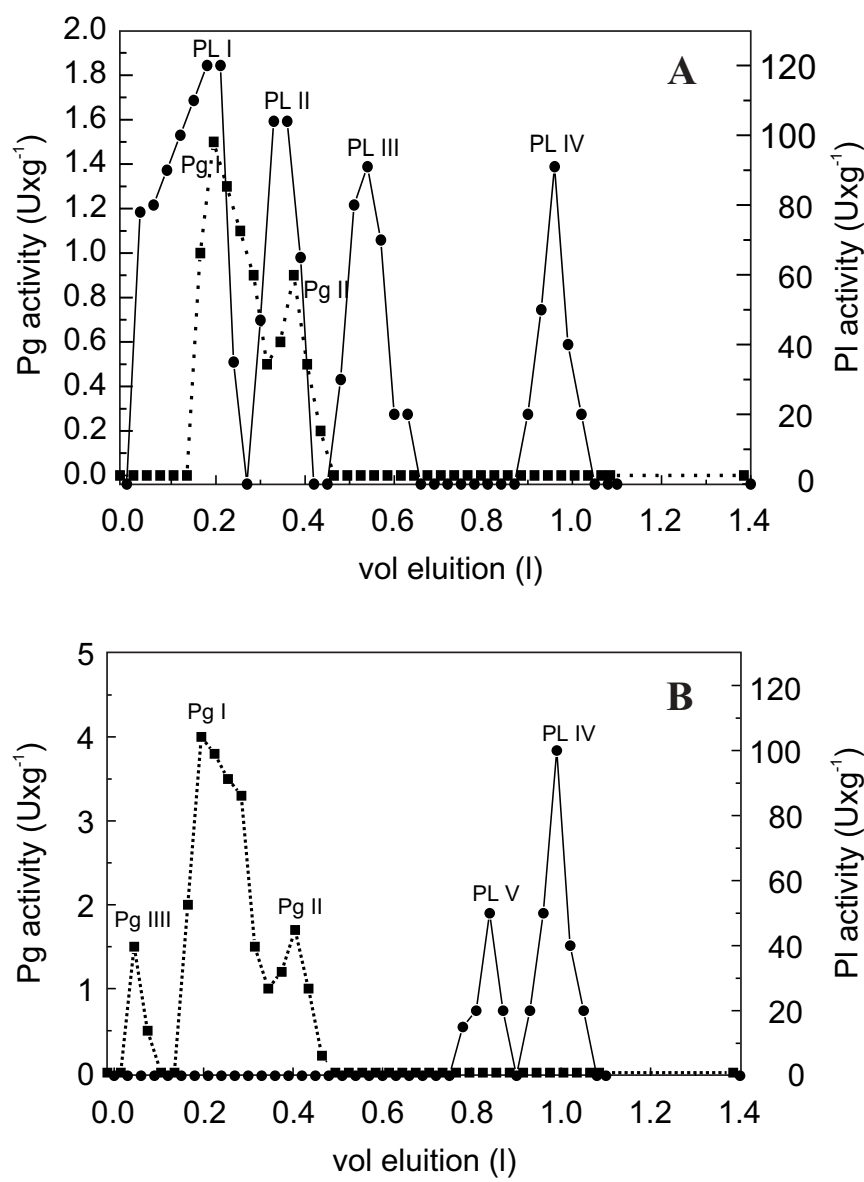

Figure 2. Gel filtration of pectinases from Penicillium vericatum Rfc3 on sephadex G50.The column was equilibrated with 50 $\mathrm{mM}$ Tris- $\mathrm{HCl}$ buffer at $\mathrm{pH}$ 7.0. The enzymes eluition was developed by the same buffer at a flow rate of $24 \mathrm{ml} / \mathrm{h}$, and the effluent was collected in $6 \mathrm{ml}$ fractions. $\mathrm{a}=$ crude enzyme obtained after 2 days and $b=$ crude enzyme obstained after 14 days of fermentation. $\square$ polygalacturonase; pectin lyase.
$(11,15,21,24,38)$ indicating that this is characteristic of fungi and bacteria. Other hemicellulolytic enzymes presented similar profiles (22).

\section{Enzyme characterization}

Characterization of the fractions of polygalacturonase (I) and pectin lyase (IV) obtained by gel filtration in Sephadex G50 was carried out. Pg exhibited maximal activity at pH 5.0 (Fig.3 a) and $\mathrm{Pl}$, at $\mathrm{pH} 10.5$ (Fig. 3b). Pg II was stable at pH 5.0-8.0 and maintained $80 \%$ of its activity at $\mathrm{pH} 9.0$ (Fig. 3a). Pl was more sensitive to $\mathrm{pH}$ variation, presenting maximum stability at $\mathrm{pH}$ 3.5-4.5 which declined to $80 \%$ at $\mathrm{pH} 5.0$ and to $60 \%$ at $\mathrm{pH} 6.0$ (Fig. 3b).

The optimum temperature for $\mathrm{Pg}$ activity was $55^{\circ} \mathrm{C}$, presenting $90 \%$ of the maximum activity at $60^{\circ} \mathrm{C}$ and $67 \%$ at $65^{\circ} \mathrm{C}$ (Fig. 4a). As illustrated in Fig. 4b, Pl presented optimal activity at $50^{\circ} \mathrm{C}$ and $67 \%$ of this activity at $55^{\circ} \mathrm{C}$. After incubation
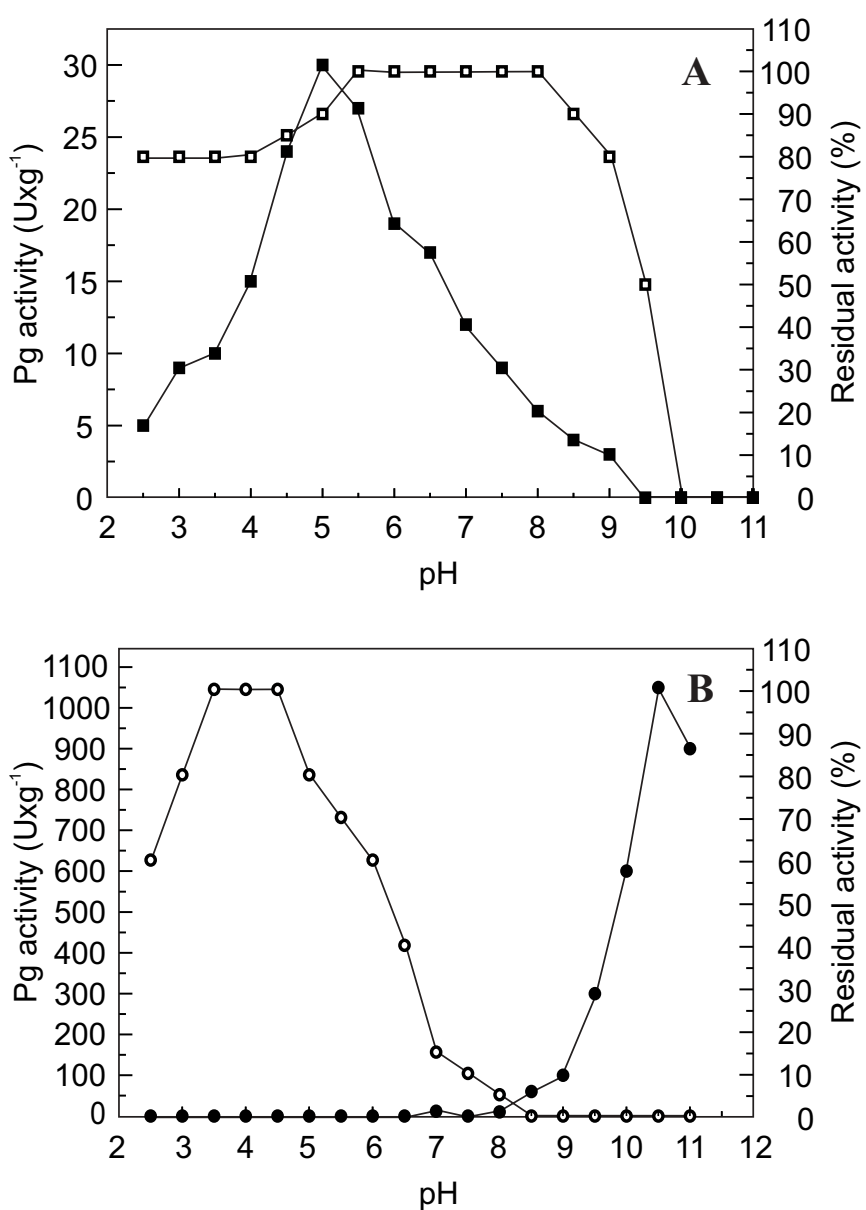

Figure 3. Effect of pH on the Polygalacturonase (a) and Pectin lyase (b) activity and stability. Full symbol = enzyme activity; open symbol= enzyme stability. 
at $40^{\circ} \mathrm{C}$ for $1 \mathrm{~h}$, the retained activities of $\mathrm{Pg}$ and $\mathrm{Pl}$ were $100 \%$ and $80 \%$ respectively. After $1 \mathrm{~h}$ at $50^{\circ} \mathrm{C} 55 \%$ of original Pg activity was maintained while the same conditions of incubation reduced original Pl activity by $60 \%$ (Fig. 4 a,b).

Previous data indicated differences between physicochemical properties of enzyme in crude solution (data not shown) and $\mathrm{Pg}$ and $\mathrm{Pl}$ fractions. Pg I fraction presented higher optimum temperature than crude enzyme solution, which maximal activity between 45 to $50^{\circ} \mathrm{C}$. The fraction studied was stable in neutral $\mathrm{pH}$ while activity of the crude enzyme was highest in acidic $\mathrm{pH}$. PI IV fraction showed to be more alkalophilic (optimum $\mathrm{pH}$ was $10.5)$ and more thermostable than the crude enzyme, which presented optimum $\mathrm{pH}$ of 8.5 and maintained only $30 \%$ of the original activity at $40^{\circ} \mathrm{C}$. These data indicate that pectinases with different properties were produced.

The optimum $\mathrm{pH}$ (5.0) found for Pg I from P. viridicatum $\mathrm{Rfc} 3$ is comparable to that from other fungal strains. On the
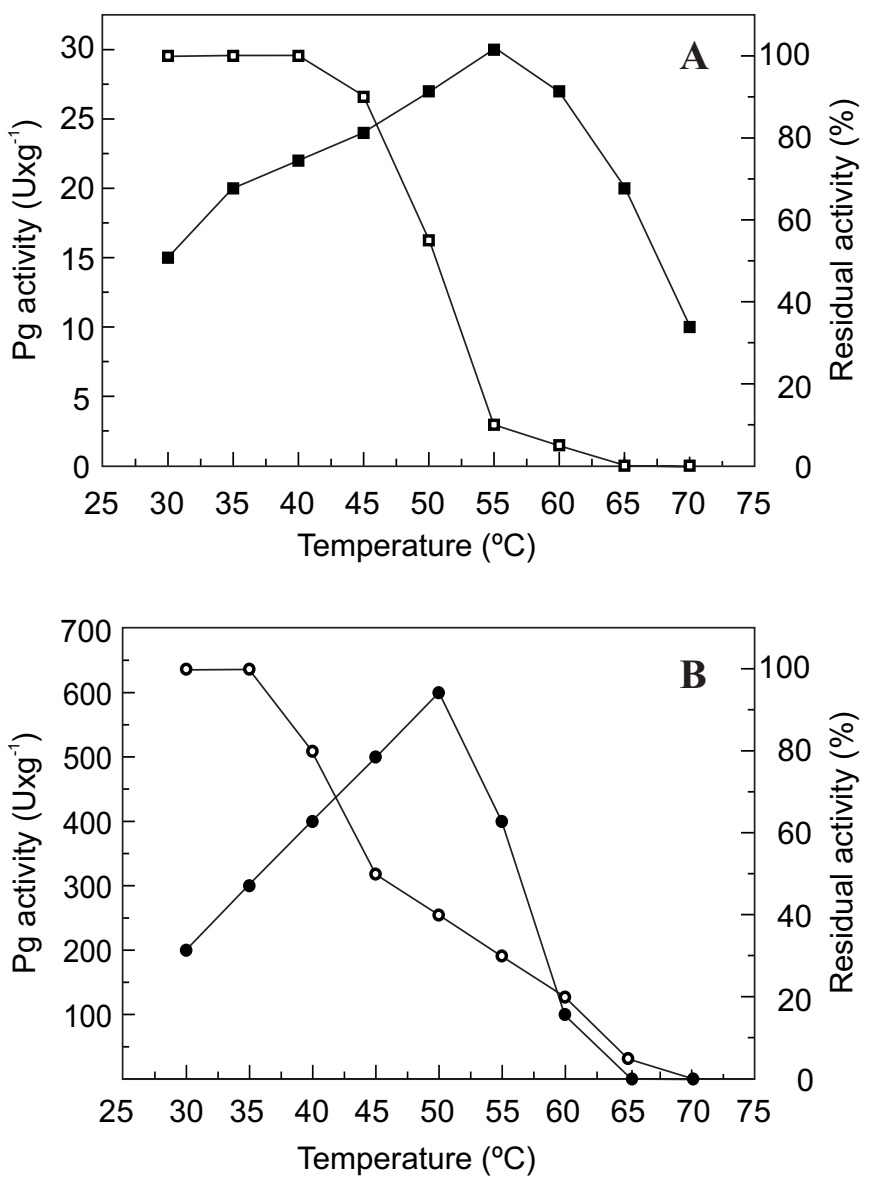

Figure 4. Effect of temperature on the Polygalacturonase (a) and Pectin lyase (b) activity and stability. Full symbol = enzyme activity; open symbol= enzyme stability. other hand, optimum pH for PI IV (10.5-11.0) is above the one found for fungal $\mathrm{Pl}$ (42), being similar to pectinases from bacteria (Bacillus sp) described by Kobayashi et al. (23).

In terms of thermal stability and optimum temperature for activity, pectinases from $P$. viridicatum $\mathrm{Rfc} 3$ were similar to those reported for several fungal species $(36,37)$. Pectinases from Aspergillus strains have been described as susceptible to denaturation in temperature above $50^{\circ} \mathrm{C}(5,17,41)$.

The present work shows that is feasible to use agroindustrial wastes and agro-industrial by-product for production of polygalacturonase and pectin lyase by Penicillium viridicatum strain $\mathrm{Rfc} 3$. This newly isolated fungus is able to produce extracellular polygalacturonase and pectin lyase during solid state fermentation, in which different pectinases are produced.

\section{ACKNOWLEDGEMENTS}

The authors wish to thank the Fundação de Amparo à Pesquisa do Estado de São Paulo (FAPESP) for financial support.

\section{RESUMO}

\section{Produção de pectinases por Penicillium viridicatum RFC3 através de fermentação em estado sólido, usando resíduos agrícolas e sub-produtos agroindustriais}

A produção de pectina liase $(\mathrm{Pl})$ e poligalacturonase $(\mathrm{Pg})$ por cepa de Penicillium viridicatum Rfc3, recentemente isolada, foi estudada por meio de fermentação em estado sólido usando bagaço de laranja, tegumento de milho, farelo de trigo e cascas de manga e banana como fontes de carbono. Quando os resíduos foram utilizados isoladamente, o valor máximo de atividade de $\mathrm{Pg}$ $\left(30 \mathrm{U} \mathrm{g}^{-1}\right)$ foi observado em meio de farelo de trigo, enquanto que o valor máximo para atividade de $\mathrm{Pl}\left(2000 \mathrm{U} \mathrm{g}^{-1}\right)$ foi obtido em meio de bagaço de laranja. Misturas de cascas de banana ou de manga com bagaço de cana-de-açúcar (50\% p/p), resultaram em aumento na produção tanto de $\mathrm{Pl}$ quanto de $\mathrm{Pg}$, quando comparado com os experimentos nos quais esses materiais foram usados isoladamente. A mistura de bagaço de laranja e farelo de trigo (50\%) elevou a produção de $\mathrm{Pg}$ e $\mathrm{Pl}$ para $55 \mathrm{U.g}^{-1}$ e 3540 $\mathrm{U} . \mathrm{g}^{-1}$, respectivamente. $\mathrm{O}$ fracionamento das enzimas presentes na solução enzimática bruta, através de filtração em gel Sephadex G50, resultou na obtenção de diferentes frações de Pl e de Pg. As frações de $\mathrm{Pg}$ e $\mathrm{Pl}$, as quais foram caracterizadas, apresentaram atividade ótima em pH 5,0 e 10,5, respectivamente. A atividade máxima da fração de $\mathrm{Pg}$ foi obtida a $55^{\circ} \mathrm{C}$ e, para $\mathrm{Pl}$, a $50^{\circ} \mathrm{C}$. A Pg foi estável em valores de $\mathrm{pH}$ próximos à neutralidade e a $40^{\circ} \mathrm{C}$, enquanto que a $\mathrm{Pl}$ foi estável em $\mathrm{pH}$ ácido e $\mathrm{a} 35^{\circ} \mathrm{C}$, por uma hora.

Palavras-chave: Penicillium viridicatum, poligalacturonase, pectina liase, "wastes, by-product". 


\section{REFERENCES}

1. Aguillar, G.; Huitron, C. Stimulation of production of extracellular pectinolytic activities of Aspergillus sp by galacturonic acid and glucose additions. Enz. Microbiol. Technol., 9: 690-696, 1987.

2. Albersheim, P. Pectin lyase from fungi. Methods Enzymol., 8: 628631,1966

3. Alkorta, I.; Garbisu, C.; Llama J.M.; Serra, J.L. Industrial applications of pectic enzymes: a review. Process Biochem., 33: 21-28, 1998.

4. Bacarat, M.C.; Valentin, C.; Muchovej, J.J.; Silva, D.O. Selection of pectinolytic fungi for degumming of natural fibers. Biotechnol. Lett., 11: 899-902, 1989.

5. Bailey, M.J.; Pessa, E. Strain and process for production of polygalacturonase. Enzyme Microb. Technol., 12: 266-271, 1990.

6. Barreto de Menezes, T.J.; Salva, J.G.; Baldini, V.L.; Papini, R.S.; Sales, A.M. Protein enrichment of citrus wastes by solid substrate fermentation. Proc. Biochem., 23: 167-171, 1989.

7. Buswell, J.A.; Cai, Y.J.; Chang, S.T.; Peterdy, J.F.; Fu, S.Y.; Yu, H.S. Lignocellulolytic enzyme profiles of edible mushroom fungi. World J. Microb. Biotech., 12: 537-542 1996.

8. Castilho, L.R.; Alves, T.L.M.; Medronho, R.A. Recovery of pectinolytic enzymes produced by solid state culture of Aspergillus niger. Process Biochem., 34: 181-186, 1999.

9. Castilho, L.R.; Alves, T.L.M.; Medronho, R.A. Production and extraction of pectinases obtained by solid state fermentation of agro-industrial residues with Aspergillus niger. Biores. Technol., 71: 45-50, 2000.

10. Chahal, D.S. Production of Trichoderma reesei cellulase system with high hydrolytic potential by solid -state fermentation. In: Leathem, G.F.; Himmel M.E.; (Eds): Enzymes in Biomass Conversion, ACS Symp. Series 460, American Chem. Soc, Whashington, 1991, p.247269

11. Crotti, L.B.; Jabopr, V.A.; Chellegatti, M.A.; Fonseca, M.J.; Said, S. Studies of pectic enzymes produced by Talaromyces flavus in submerged and solid substrate cultures. J. Basic Microbiol., 39: 2735, 1999.

12. Da Silva, R.; Franco, C.M.L.; Gomes, E. Pectinases, hemicelulases e celulases: ação, produção e aplicação no processamento de alimentos: Revisão. Bol. Sociedade Bras. Ciênc. Tecnol. Aliment., 31: 49-260, 1997.

13. Duran, N.; Esposito, E.; Innocentini-Mei, L.H.; Canhos, V.P.; A new alternative process for Kraft E1 effluent treatment. A combination of photochemical and biological methods. Biodegradation., 5: 319, 1994

14. Fonseca, M.J.V.; Said, S.; The pectinase produced by Tubercularia vulgaris in submerged culture using pectin or orange-pulp pellets as inducer. Appl. Microbiol. Biotechnol., 42: 32-35, 1994.

15. Fonseca, M.J.V.; Said, S. Sequential production of pectinases by Penicillium frequentans. World J. Microbiol. Biotechnol., 11: 174177, 1995

16. Galiotou-Panayotou, M.; Rodis, P.; Kapantai, M. Enhanced polygalacturonase production by Aspergillus niger NRRL-364 grown on supplemented citrus pectin. Lett. Apll. Microbiol., 17: 145-148, 1993.

17. Galiotou-Panayotou, M.; Kapantai, M.; Kalantzi, O. Growth conditions of Aspergillus sp ATHUM-3482 for polygalacturonase production. Appl. Microbiol. Biotechnol., 47: 425-429, 1997.

18. Garzón, C.G. and Hours, R.A. Citrus waste: an alternative substrate for pectinase production in solid-state culture. Biores. Technol., 39: 93-95, 1992.

19. Guevara, M.A.; Gonzalez-Jen, M.T.; Estevez, P. Multiple forms of pectic lyases and polygalacturonases from Fusarium oxysporum $\mathrm{f}$. sp redicais lycopersici: Regulation of their synthesis by galacturonic acid. Canadian J. Microbiol., 43: 245-253, 1997.

20. Hang, Y.D.; Woodanms, E.E. Production of fungal polygalacturonase from apple pomace. Lebensm. Wiss. U. Technol., 27: 194-196, 1994.
21. Hours, R.A.; Voget, C.E.; Ertola, R.J. Some factories affecting pectinase production from apple pomace in solid states cultures. Biological wastes., 24: 147-157, 1988.

22. Ismail, A.S. Utilization of orange peels for the production of multienzyme complexes by some fungal strains. Process Biochem., 1: 645-650, 1996.

23. Kobayashi, T.; Hatada, Y.; Higaki, N.; Lusterio, D.D.; Ozawa, T.; Koike, K.; Kawai, S.; Ito, S. Enzymatic properties and deduced amino acid sequence of a high-alkaline pectate lyase from na alkaliphilic Bacillus isolate. Bioch. Biophys. Acta., 1427: 145-154, 1999.

24. Leone, G.; Heuvel, J.; Van Den Heuvel, J. Regulation by carbohydrates of the sequential in vitro production of pectic enzymes by Botrytis cinerea. Can. J. Bot., 65: 2133-2141, 1987.

25. Miller, G.L. Use of dinitrossalicylic acid reagent for determination of reducing sugars. Anal Chem., 31: 426-428, 1959.

26. Mitchell, D.A.; Do, D.D.; Greenfield, P.F.; Doelle, H.W. A semimechanistic mathematical model for growth of Rhizopus oligosporus in a model solid-state fermentation system. Biotechnol. Bioeng., 38: 353 62, 1991.

27. Mitchell, D.A.; Krieger, N.; Stuart, D.M.; Pandey, A. New developments in solid-state fermentation. II. Rotational approaches to the design, operation and scale-up of bioreactors. Process. Biochem., 35: 1211-1225, 2000.

28. Mutlu, M.; Srioglu, K.; Demir, N.; Ercan, M.T.; Acar, J. The use of commercial pectinase in fruit juice industry. Part I: viscosimetric determination of enzyme activity. J. Food Engen., 41: 147-150, 1999.

29. Naidu, G.G.N.; Panda, T. Production of pectolytic enzymes- a review. Bioprocess Eng., 19: 355-361, 1998.

30. Ooijkaas, L.; Weber, F.J.; Buitelaar, R.M.; Tramper, J.; Rinzema, A. Defined media and inert supports: their potential as solid-state fermentation production systems. Trends Biotechnol., 18: 356-360, 2000 .

31. Oriol, E.; Schettino, B.; Viniegra-Gonzales, G.; Raimbaut, M. Solidstate culture of Aspergillus niger on support. J. Ferment. Technol., 66: 57-62, 1988.

32. Oudot, J.; Dupont, J.; Haloui, S.; Roquebert, M.F. Biodegradation potential of hydrocarbon-assimilating tropical fungi. Soil Biol. Biochem., 25: 1167-1173, 1993.

33. Pandey, A.; Soccol, C.R.; Nigam, P.; Soccol, V.T. Biotechnological potential of agro-industrial residues. I: sugar cane bagasse. Bioresource Technol., 74: 69-80, 2000.

34. Pilnik, W.; Voragen, A.G.J. Pectic enzymes in fruit and vegetable juice manufature. In: Nagodawithama, T.; Reed, G. (eds). Enzymes in Food Processing, Academic Press, New York 1993, p.363-399.

35. Reid, I.; Ricard, M. Pectinase in papermaking: solving retention problems in mechanical pulps bleached with hydrogen peroxide Enz. Microbiol. Technol., 26: 115-123, 2000.

36. Riou, C.; Freyssinet, G.; Feure, M. Purification and characterization of extracellular pectinolytic enzymes produced by Sclerotinia sclerotiorum. Appl. Env. Microbiol., 58: 578-583, 1992.

37. Ryazanova, L.P.; Mikhaleva, N.I.; Solov'eva, I.V.; Boev, A.V.; Okunev, O.N.; Kulaev, I.S. Pectolytic enzymes from Aspergillus heteromorphus. Appl. Biochem. Microbiol., 32: 1-6, 1996.

38. Soares, M.M.C.N.; Da Silva, R.; Gomes, E. Screening of bacterial strains for pectinolytic activity characterization of the Pgase produced by Bacillus species. Rev. Microbiol., 30: 229-303, 1999.

39. Soares, M.M.C.N.; Da Silva, R.; Carmona, E.C.; Gomes, E Pectinolytic enzymes production by Bacillus species and their potential application on juice extraction. World J. Microbiol. Biotechnol., 17: 79-82, 2001.

40. Solis-Pereira, S.; Favela-Torres, E.; Viniegra-Gonzales,G.; GutierrezRofas, M. Effects of different carbon source on the synthesis of pectinase by Aspergillus niger in submerged and solid state fermentations. Appl. Microbiol. Biothnol., 39: 36-41, 1993.

41. Ueda, S.; Yusaku, F.; Lim, J.Y. Production and some properties of pectic enzymes from Aspergillus oryzae A-3. J. Appl. Biochem., 4: 524-532, 1982

42. Whitaker, J.R. Microbial Enzymes and Biotechnology, In: Fogarty, W.M.; Kelly, C.T. (eds). Elsevier, London, 1990, p.133-176. 